PERM JOURNAL OF PETROLEUM AND MINING ENGINEERING

ВЕСТНИК ПНИПУ. ГЕОЛОГИЯ. НЕФТЕЕАЗОВОЕ И ГОРНОЕ ДЕЛО

ISSN 2224-9923

Volume/TOM 16 №2 2017

http://vestnik pstu.ru/geo/

УДК 553.98; 624.131

Article / Статья

(c) PNRPU / ПНИПУ, 2017

\title{
STUDY OF REGULARITIES AND CONSTRUCTION OF MATHEMATICAL MODELS OF HYDROCARBON DISTRIBUTION IN A SECTION ON TERRITORIES OF OIL TREATMENT ENTERPRISES
}

\section{Pavel A. Krasilnikov, Valerii V. Seredin}

Perm State National Research University (15 Bukireva st., Perm, 614068, Russian Federation)

\section{ИЗУЧЕНИЕ ЗАКОНОМЕРНОСТЕЙ И ПОСТРОЕНИЕ МАТЕМАТИЧЕСКИХ МОДЕЛЕЙ РАСПРЕДЕЛЕНИЯ УГЛЕВОДОРОДОВ ПО РАЗРЕЗУ НА ТЕРРИТОРИЯХ НЕФТЕПЕРЕРАБАТЫВАЮЩИХ ПРЕДПРИЯТИЙ}

\section{П.А. Красильников, В.В. Середин}

Пермский государственный национальный исследовательский университет (614068, Россия, г. Пермь, ул. Букирева, 15)

Received / Получена: 17.03.2017. Accepted / Принята: 19.04.2017. Published / Опубликована: 30.06.2017

Key words:

oil contaminated territories,

hydrocarbons, penetration depth, modeling, mathematical models, ground, mathematical statistics, geostatistics, artificial pollution, geology, geoecology.

\begin{abstract}
Nowadays, active human economic activity leads to significant man-made pollution. In a number of cases geological environment is polluted with hydrocarbons by an accident. That leads to change in physical and mechanical properties of grounds and has negative impact on entire an ecosystem. This work is devoted to identification of regularities and construction of mathematical models for distribution of hydrocarbons along a section on territories of oil refineries, which allow predicting the level of pollution in case of accidental hydrocarbon spills. Obtained information allows estimating changes and predicting bearing capacity of grounds during accidental oil spills. Study of hydrocarbon distribution in ground massif is based on identification of natural and artificial regularities, which are described by math body. This gives a methodological approach to study these regularities depending on geological conditions of territories that are subject to risk of accidental oil spills.

Three models of distribution of hydrocarbons along a section are revealed. They are controlled by geological conditions (lithology and depth of occurrence of an aquifer). Based on revealed regularities, mathematical models are developed. They allow to predict degree of ground contamination with hydrocarbons in terms of geological indexes (thickness of loam and crushed rock and depth of occurrence of sandstones). As a result of statistical processing, influence of geological structure on depths of hydrocarbon penetration and content of hydrocarbons is established.

It is confirmed that distribution of hydrocarbons is significantly influenced by type of rocks and their sorption ability for hydrocarbons, penetration properties (porosity and permeability) and water saturation. In case near-surface zone of the earth is composed of sands that have low sorption ability for hydrocarbons, high open porosity and high penetration properties, a hydrocarbon contamination zone will be small in comparison with zone composed of clays or loam.
\end{abstract}

В настоящее время активная хозяйственная деятельность человека приводит к значительному техногенному загрязнению. В ряде случаев в результате аварийных происшествий происходит загрязнение геологической среды углеводородами, что приводит к изменению физико-механических свойств грунтов и отрицательной сказывается на экосистеме в целом. Данная работа посвящена выявлению закономерностей и построению математических моделей распределения углеводородов по разрезу на территориях выявлению закономерностей и построению математических моделей распределения углеводородов по разрезу на территориях
нефтеперерабатывающих предприятий, позволяющих прогнозировать глубину загрязнения в случае аварийных разливов углеводородов. Полученная информация позволит оценить изменения и спрогнозировать несущую способность грунтов при аварийных разливах нефтепродуктов. Изучение особенностей распределения углеводородов в грунтовом массиве основывается на выявлении природно-техногенных закономерностей, которые описываются с помощью математического аппарата. Тем самым дается методологический подход к изучению этих закономерностей в зависимости от геологических условий территорий, подверженных риску аварийного разлива нефтепродуктов.

Выявлены три модели распределения углеводородов по разрезу, которые контролируются геологическими условиями (литологией и глубиной залегания водоносного горизонта). На основании выявленных закономерностей разработаны математические модели, позволяющие по геологическим показателям (мощности суглинка и щебенистого грунта, а также по глубине залегания песчаников) прогнозировать степень загрязнения грунтов углеводородами. В результате статистической обработки установлено влияние геологического строения на глубины проникновения и содержание углеводородов.

Было подтверждено, что на распределения углеводородов существенное влияние оказывает тип пород и прежде всего их сорбционная способность к углеводородам, фильтрационные свойства (пористость и проницаемость) и водонасышенность. В случае, если приповерхностная зона земли сложена песками, которые имеют низкую сорбционную способность к углеводородам, высокую открытую пористость и высокие фильтрационные свойства, зона загрязнения углеводородами будет минимальна по сравнению с тем, если бы она была сложена из глин или суглинков.

Pavel A. Krasilnikov (Authors ID in Scopus: 56667332500) - PhD in Geological Sciences, Associate Professor at the Department of Engineering Geology and Protection of Mineral Deposits (tel.: +007 34223964 39, e-mail: Kafedra.ingeo@gmail.com). The contact person for correspondence.

Valerii V. Seredin (Authors ID in Scopus: 56974744000) - Doctor of Geological and Mineralogical Sciences, Professor, Head of the Department of Engineering Geology and Protection of Mineral Deposits (tel.: +007 34223964 39, e-mail: Kafedra.ingeo@gmail.com).

Красильников Павел Анатольевич - кандидат геологических наук, доцент кафедры инженерной геологии и охраны недр (тел.: +007 3422396439 , e-mail: Kafedra.ingeo@gmail.com). Контактное лицо для переписки.

Середин Валерий Викторович - доктор геолого-минералогических наук, профессор, заведующий кафедрой инженерной геологии и охраны недр (тел.: +007 3422396439, e-mail: Kafedra.ingeo@gmail.com). 


\section{Introduction}

Nowadays, active human economic activity leads to significant man-made pollution. In a number of cases geological environment is polluted with hydrocarbons by an accident. That leads to change in physical and mechanical properties of grounds and has negative impact on an entire ecosystem [1-3].

Studies conducted by I. Mazur [4] show that oil losses caused by emergency spills is about $3 \%$ of its annual production. It is clear from the above mentioned that knowledge of the depth of penetration and regularities in distribution of spilled hydrocarbons in ground is important and relevant.

According to the analysis of works of foreign authors there is quite a lot of publications are devoted to penetration of hydrocarbons into grounds.

Over the past 50 years the number of publications on ground hydrocarbon contamination has exceeded 10,000 (according to the Scopus reference database). And the number of articles increases every year. In 2014987 journal articles from the Scopus database were devoted to this subject.

After specification on the query to search within the problem of interest (distribution of hydrocarbons in ground in case of oil spills), the Scopus abstract database finds about 150 papers. It is notable, that interest to this problem is maintained at the same level every year. There are 12 papers in 2012 and 16 papers in 2016 that were devoted to this topic. Statistics show that the problem of hydrocarbon distribution in ground is now very relevant.

Most of the work devoted to the subject of the study was published in the United States, followed by China, Canada, Nigeria, Great Britain (Fig. 1, a). Russia occupies the $23^{\text {rd }}$ place in this list. That is caused primarily by the fact that Russian scientists are published quite a bit in journals from the list of Scopus, but not by the lack of developments on this issue.

Most of the work ( $>80 \%$ ) was published in journals on sciences of the earth and natural environment (Fig. 1, $b$ ).

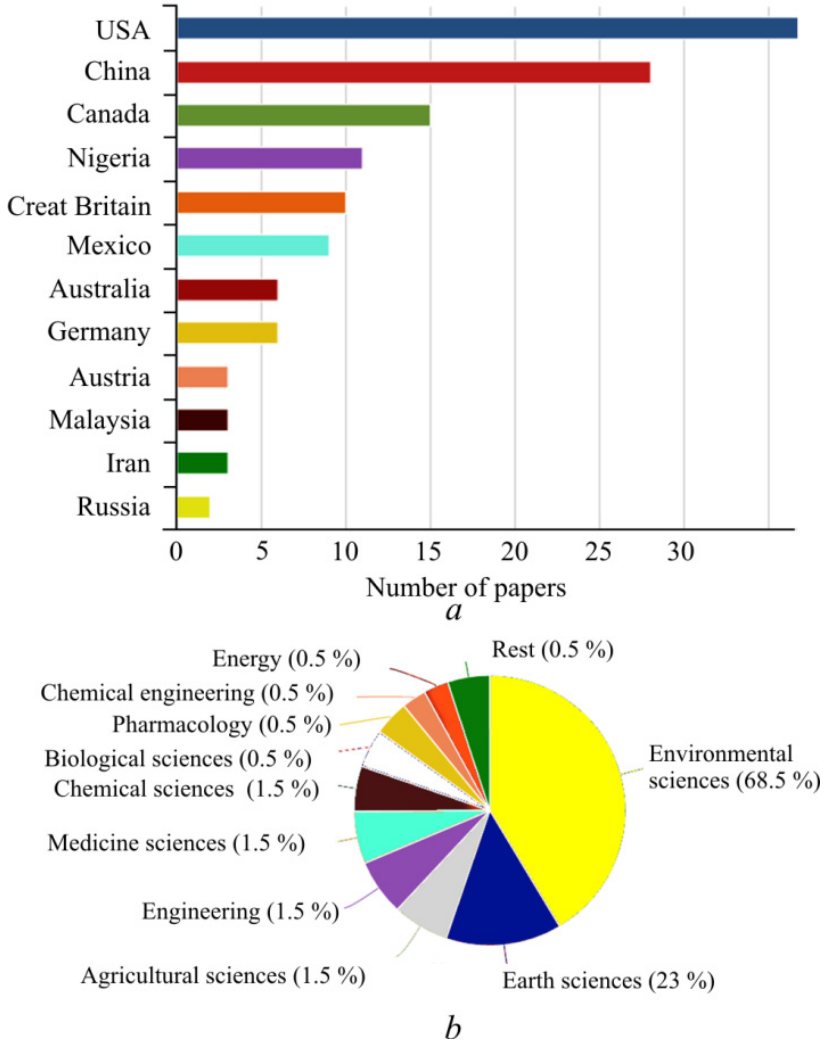

Fig. 1. Publication activity of countries on the subject of research $(a)$;

branch affiliation of published works $(b)$

The problems of hydrocarbon pollution of the environment were studied by various researchers. In 1979 there was a whole program called CONCAWE, devoted to the protection of groundwater from pollution by oil products. Following authors dealt and are dealing with the questions of study of hydrocarbon penetration rate: M.F. Fingas, S. Grimaz, S. Allen, J. Stewart, G. Dolcetti, S. Halmemies, S. Gröndhal, K. Nenonen, T. Tuhkanen, J.M. Keller, C.S. Simmons, V. Malk, S. Simpanen, Q. Zhang, G. Wang, N. Sugiura, A. Akbari, M. Ardestani, J. Shayegan, B. Zogala, R. Dubiel, W.M. Zuberek, M. Rusin-Zogala, M. Steininger, R. Iturbe, C. Flores, A. Castro, L.G. Torres etc. [5-15].

S. Halmemies, S. Gröndhal, K. Nenonen, T. Tuhkanen studied the time of penetration of oil into various grounds under laboratory conditions [9].

The deepest research on the penetration of hydrocarbons into the ground was performed by English and Italian scientists S. Grimaz, S. Allen, J.R. Stewart, G. Dolcetti and is presented in their 
joint work "Express method to evaluate the rate of penetration of hydrocarbons into the ground immediately after an accidental spill for rapid response". It provides an express method to predict the rate of penetration of hydrocarbons into the ground after an accidental spill on the ground. The model proposed by them is applicable under the following conditions:

a) evaporation occurs only from the surface of the pool until the oil has penetrated into the ground;

b) oil viscosity and density remain constant over the time;

c) advective processes are dominant in penetration;

d) Darcy's law is acceptable for determination of the rate of penetration into the soil [9].

Experimental studies of distribution of hydrocarbons in grounds under laboratory conditions were published in [1, 16-20]. They contain calculated models that allow predicting the rate of penetration of hydrocarbons in time:

- for sand of medium size

$$
V_{\text {s.m.d }}=24.0391-0.7733 t,
$$

where $V_{\text {s.m.d }}$ is for oil penetration rate in dry sands of medium size, $\mathrm{mm} /$ day; $t$ is for penetration time, day;

- for fine sand

$$
V_{\text {s.f.d }}=16.5558-0.5321 t \text {, }
$$

where $V_{\text {s.f.d }}$ is for oil filtration rate in fine sands, $\mathrm{mm} /$ day; $t$ is for penetration time, day;

- for clay

$$
V_{\text {c.d }}=8,101-0,2309 t,
$$

where $V_{\text {c.d }}$ is for oil filtration rate in clays, $\mathrm{mm} /$ day; $t$ is for penetration time, day.

Due to the fact that laboratory studies were carried out with ground in air dry state of the same fractional composition, then these experiments do not reflect real natural conditions and are the first step in understanding the regularities of hydrocarbon distribution along the section. Therefore, it is need to study regularities of hydrocarbon distribution in field conditions. This article presents results of geostatistical processing of field work data.
The aim of the study is to identify regularities and build mathematical models for distribution of hydrocarbons along a section on the territories of oil refineries, which allow predicting the depth of contamination in case of accidental spills.

The information obtained will allow estimating changes in the bearing capacity of ground in case of hydrocarbon contamination [2, 19, 21, 22].

Study of features of distribution of hydrocarbons in the ground is based on identification of natural and man-caused regularities, which are described by means of a mathematics [16, 23-25]. That gives a methodological approach to study the regularities, depending on the geological conditions in which territories were formed and are the subject to risk of accidental oil spills.

\section{Initial data used to identify regularities and build mathematical models}

To identify regularities and build mathematical models field and experimental data obtained during cleaning of territory contaminated with oil products of oil refinery were used $[16,17,20]$.

To determine the content of hydrocarbons in the ground field studies were carried out including drilling of wells, selection of monoliths, study of core material and hydrogeological, geomorphological and other conditions.

In order to optimize exploration network, data on the variability of the least mature geological and exploration parameters (hydrocarbons) of the investigated territory was used. Well placement parameters were determined from the following considerations.

At the first stage, testing was carried out uniformly across the area taking into account sources of possible contamination (ethylbenzene workshop - block 401; containers with finished products - blocks 404 and 405) and data of enquiry of workers about the spills of organic compounds into the ground. At the second stage well network was sealed. Maximum number of wells was drilled on the site of the workshop of the $31^{\text {st }}$ chemical plant (Fig. 2).

In total, 250 wells were drilled on the site of study. Wells were drilled on anthropogenic, 
Quaternary sediments and rocks of Sheshminsky formation where more than 1160 samples were taken to determine the hydrocarbon content.

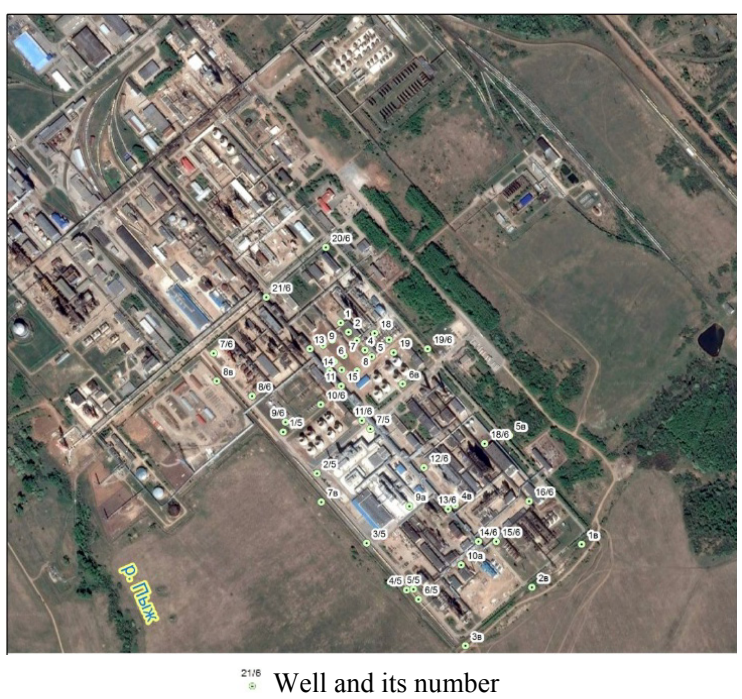

Fig. 2. Scheme of well placement

Quantitative content of petroleum products in the ground was determined using chromatograph Chrom with a flame ionization detector according to the generally accepted procedure.

\section{A brief physical and geographical description}

The relief of the site is characterized by the presence of flattened surfaces and slopes formed as a result of flat flushing, deep and lateral erosion of the Kama river, its tributaries and temporary outflow.

There are several objects defined within the section in terms of geomorphology such as a slope IV of the left bank terrace above the flood-plain of the Kama river (right side of the valley of the Pyzh river), III floodplain terrace of the Kama river complicated by the valley of the Pyzh river.

According to the dominant slope forming processes, the greater part of the slope IV of the terrace above the flood-plain refers to the deluvial terrace when the south-west part, facing the valley of the river Pyzh, is its right-bank side and represents an erosive slope.

\section{Features of the geological structure of the area studied}

Anthropogenic deposits are mainly sand and crushed stone. Thickness of these deposits varies from 0 to $1.3 \mathrm{~m}$. Quaternary rocks are represented by loam, sands and gritty-crushed ground (Fig. 3).

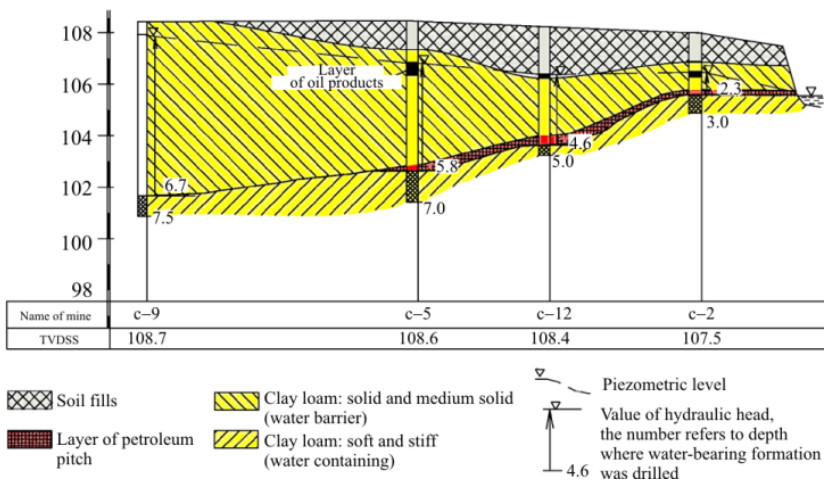

Fig. 3. Geological section along wells

Loams have dark brown color and are made from solid to semi-solid consistency, dense, with inclusions of gravel of argillite. The thickness of the loam varies from 0.8 to $3.7 \mathrm{~m}$. The maximum thickness is discovered by wells $16-18$, the smallest by wells $7,8,15$.

Sands are gray, wet, fine and medium-grained, medium-density. Sands have a local distribution (wells $7,15,17,19)$. The maximum open thickness is $1.7 \mathrm{~m}$.

The grit-crushed soil is represented by fragments of mudstone with loamy aggregate up to $20 \%$. It also has a local distribution. The maximum thickness is opened by a well 2 and is $1.3 \mathrm{~m}$.

Rocks of Sheshminsky age are represented by sandstones and siltstones. Sandstones have gray color and are fine-grained, dense, fractured, on clay-calcareous cement. Thickness of sandstones varies from 0.5 to $3.8 \mathrm{~m}$.

Siltstones have dark cherry color and are medium strength, fractured, their thickness varies also within wide limits from 0 to $3.8 \mathrm{~m}$.

\section{Research methodology}

Features of distribution of contaminating matter in the section was studied in the following sequence:

- geological structure of the territory was studied;

- quantitative content of oil products, which was obtained as a result of field research, in the soil was analyzed;

- geological, probabilistic, statistical and geostatistical methods were used to establish 
regularities in the distribution of hydrocarbons in the soil massif.

\section{Results of the study}

Statistical characteristics of results of the quantitative content of petroleum products are given in Table 1.

Table 1

The main statistical characteristics of the studied substances, $\mathrm{mg} / 100 \mathrm{~g}$ of soil

\begin{tabular}{|c|c|c|c|c|c|}
\hline Parameter & 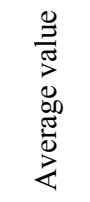 & 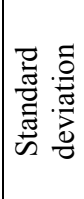 & 声 & 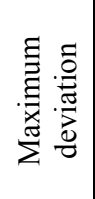 & 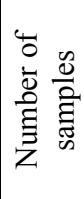 \\
\hline Benzene & 1.01 & 0.70 & 0.01 & 3.67 & 59 \\
\hline Toluene & 0.18 & 0.43 & 0.01 & 1.99 & 57 \\
\hline Ethylbenzene & 0.74 & 0.97 & 0.01 & 3.23 & 27 \\
\hline M-paraxylene & 0.25 & 0.42 & 0.004 & 3.14 & 71 \\
\hline Orthoxilol & 0.15 & 0.12 & 0.005 & 0.84 & 70 \\
\hline Styrene & 0.45 & 1.22 & 0.006 & 6.00 & 43 \\
\hline Isobutyric aldehyde & 10.21 & 11.16 & 0.40 & 44.80 & 16 \\
\hline Isobutyl alcohol & 20.65 & 17.11 & 2.50 & 51.21 & 16 \\
\hline Butyl alcohol & 15.56 & 24.60 & 1.60 & 92.80 & 30 \\
\hline 2-Ethylhexanol & 39.77 & 74.37 & 2.00 & 172.57 & 5 \\
\hline 2-Ethylhexanal & 34.56 & 72.19 & 1.90 & 244.00 & 11 \\
\hline Depth of sampling, $\mathrm{m}$ & 2.32 & 1.99 & 0.1 & \begin{tabular}{|l|}
9.0 \\
\end{tabular} & - \\
\hline
\end{tabular}

Aromatic hydrocarbons are colorless liquids with a specific smell, lighter than water and do not dissolve in water, but they readily dissolve in organic solvents such as alcohol, ether and acetone. The physical properties of some arenas are presented in Table 2 .

Analysis of the distribution of hydrocarbons along the section shows that in the stratum of study, benzene does not have a regular distribution. Meta-xylene and para-xylene are found in a significant number of samples. There is an implicit trend according to which the higher the depth the smaller the content of meta-xylene and paraxylene. The distribution of the sample is lower in this indicator than in benzene. Ortho-xylene is also found in many samples, its distribution in the section is a subject to the same regularity as metaxylene and para-xylene. Styrene, ethyl benzene and toluene are found in small amounts of samples. So, a clearly expressed law of their distribution over the section is difficult to establish. Fig. 4 presents a three-dimensional model of hydrocarbon distribution in a soil massif created in the Voxler software.

Table 2

Physical properties of some arenas

\begin{tabular}{|c|c|c|c|c|c|}
\hline $\begin{array}{l}\stackrel{\Xi}{\Xi} \\
\text { Z }\end{array}$ & $\begin{array}{l}\frac{\pi}{\vec{\Xi}} \\
\text { 官 } \\
\text { I }\end{array}$ & 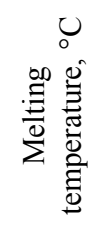 & 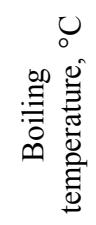 & 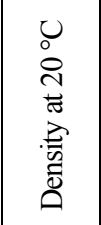 & 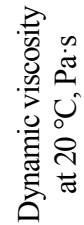 \\
\hline Benzene & $\mathrm{C}_{6} \mathrm{H}_{6}$ & +5.5 & 80.1 & 0.8790 & 0.652 \\
\hline $\begin{array}{l}\text { Toluene } \\
\text { (methylbenzene) }\end{array}$ & $\mathrm{C}_{6} \mathrm{H}_{5} \mathrm{CH}_{3}$ & -95.0 & 110.6 & 0.8669 & 0.584 \\
\hline Ethyl benzene & $\mathrm{C}_{6} \mathrm{H}_{5} \mathrm{C}_{2} \mathrm{H}_{5}$ & -95.0 & 136.2 & 0.8670 & 0.596 \\
\hline ortho- & & -25.18 & 144.41 & 0.8802 & 0.707 \\
\hline meta- & & -47.87 & 139.10 & 0.8642 & 0.548 \\
\hline para- & & 13.26 & 138.35 & 0.8611 & 0.571 \\
\hline $\begin{array}{l}\text { Styrene } \\
\text { (vinylbenzene) }\end{array}$ & $\begin{array}{c}\mathrm{C}_{6} \mathrm{H}_{5} \mathrm{CH}= \\
\mathrm{CH}_{2}\end{array}$ & -30.6 & 145.2 & 0.9060 & 0.749 \\
\hline
\end{tabular}

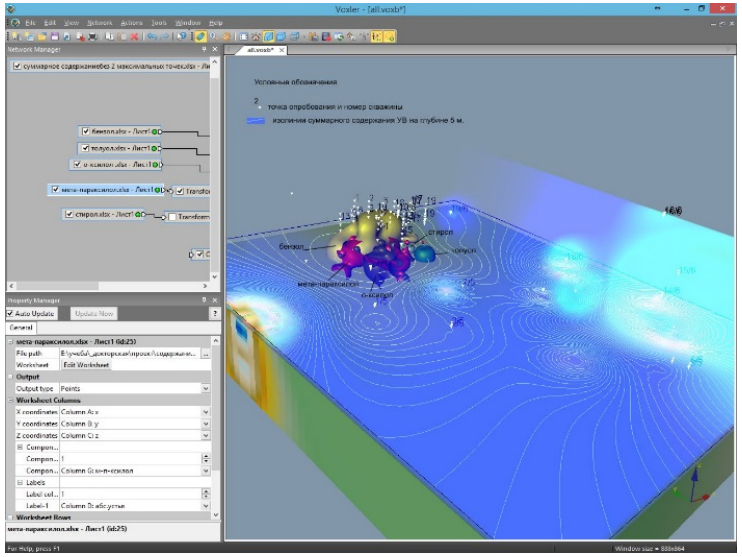

Fig. 4. 3D model of hydrocarbon distribution

As a result of studies of the distribution of hydrocarbon concentrations at different levels of the section, density curves have been plotted (Fig. 5). The plot shows that concentration distribution density is two-mode at depth of $0.25 \mathrm{~m}$. Distribution law is symmetric at concentration of soil of $1.5 \mathrm{~g} / 100 \mathrm{~g}$ at modal concentration of soil of 0 to 7 $\mathrm{mg} / 100 \mathrm{~g}$. At $0.25 \mathrm{~m}$ in depth concentration range of $7-10 \mathrm{mg} / 100 \mathrm{~g}$ of soil is not observed. The shape of the curve indicates the existence of low and high concentrations of hydrocarbons. At $0.75 \mathrm{~m}$ in depth asymmetric unimodal distribution is observed in the concentration range of soil of $0-10 \mathrm{mg} / 100 \mathrm{~g}$.

At a depth of $1.25 \mathrm{~m}$ concentration distribution is almost uniformly in the range of $0.5-3.5 \mathrm{mg} / 100 \mathrm{~g}$ of soil. At depth of $1.75 \mathrm{~m}$ the distribution is unimodal in the range of $0-5 \mathrm{mg} / 100 \mathrm{~g}$ of soil. 
There is a distribution with a large range of concentration changes is observed at $2.75 \mathrm{~m}$ in depth. Distribution is unimodal at depth of $3.5 \mathrm{~m}$ and at very low concentrations.

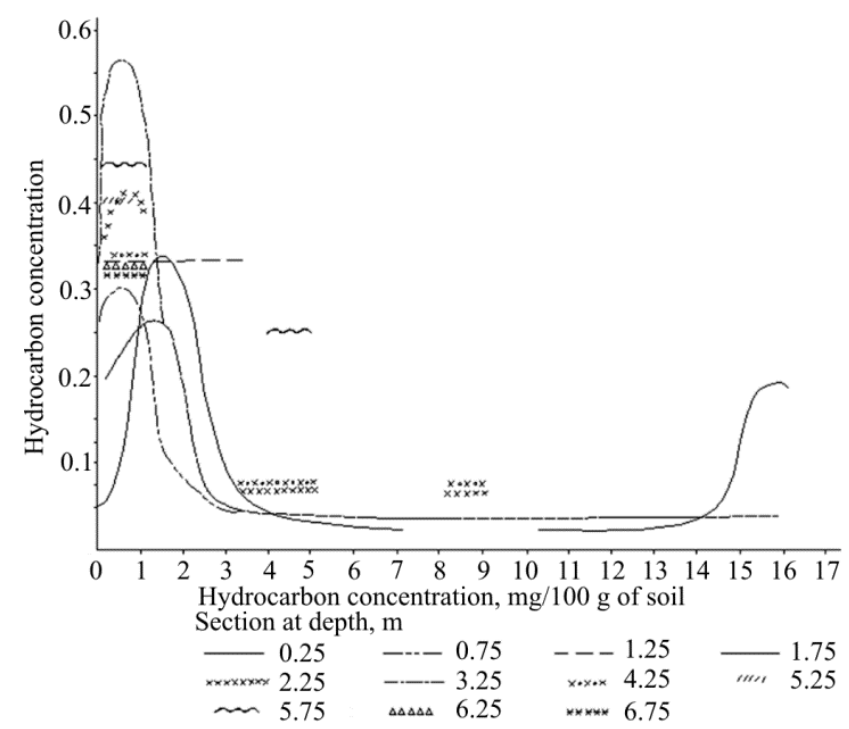

Fig. 5. Distribution of hydrocarbon concentration in depth

Beginning with a depth of $4.25 \mathrm{~m}$ a chaotic distribution of hydrocarbon concentrations is observed at values below $15 \mathrm{mg} / 100 \mathrm{~g}$ of soil. At concentrations of more than $15 \mathrm{mg} / 100 \mathrm{~g}$ of soil frequency of occurrence at different levels of the sections has the following values: $4.25 \mathrm{~m}-0.22 ; 5.25 \mathrm{~m}-0.25$; $5.75 \mathrm{~m}-0.57 ; 6.25-6.75 \mathrm{~m}-0.67$. Thus, the higher the depth the more often high concentrations is observed. The performed analysis allows to establish two levels of distribution of hydrocarbons along a section.

The first level includes hydrocarbons that are distributed almost continuously and are characterized by pronounced modal concentrations. The second level (starting from a depth of $4.25 \mathrm{~m}$ ) does not show statistically continuous hydrocarbon distributions due to the small sample representativeness. However, there are high concentrations is observed with depth.

The analysis showed that zero concentrations are practically uniformly distributed over depth (Fig. 6). The concentration $C=0.5 \mathrm{mg} / 100 \mathrm{~g}$ of soil is most often found in the interval $0.5-3.0 \mathrm{~m} . C=1.5 \mathrm{mg} / 100 \mathrm{~g}$ of soil is characterized by a unimodal distribution at depths of $0-2.5 \mathrm{~m}$.

The analysis showed that zero concentrations are practically uniformly distributed over depth (Fig. 6). The concentration of $C=0.5 \mathrm{mg} / 100 \mathrm{~g}$ of soil is most often found in the interval $0.5-3.0 \mathrm{~m} . C=1.5 \mathrm{mg} /$ $100 \mathrm{~g}$ of soil is characterized by an unimodal distribution at depths of $0-2.5 \mathrm{~m}$.

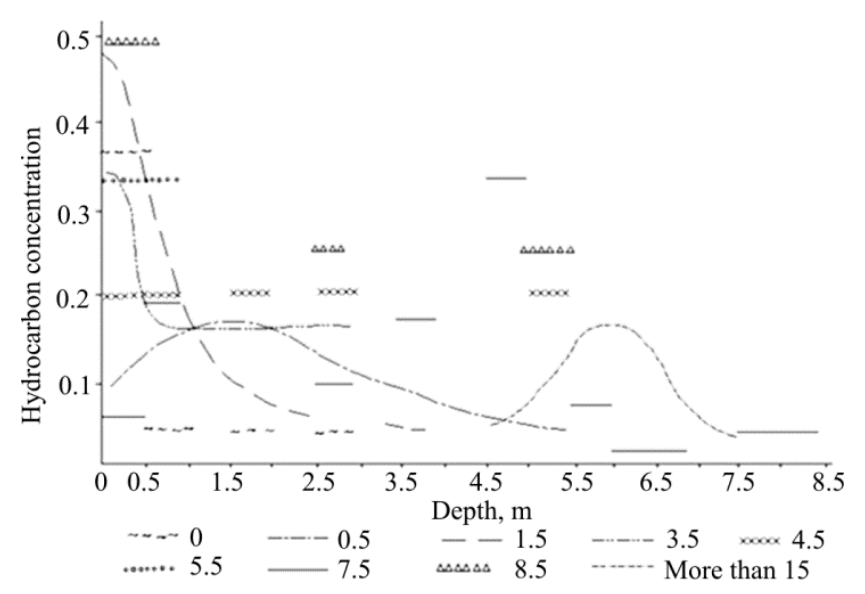

Fig. 6. Vertical distribution of hydrocarbon concentrations (mg/100 g of soil)

Analysis of the obtained curves shows that there is a directed change in the distribution laws from the uniform $(C=0)$ through symmetric $(C=0.5 \mathrm{mg} / 100 \mathrm{~g}$ soil), asymmetric $(C=1.5-3.5 \mathrm{mg} / 100 \mathrm{~g}$ soil $)$ to the chaotic ( $C=4.5 \mathrm{mg} / 100 \mathrm{~g}$ soil). The established trend indicates the dynamics of changes in hydrocarbon concentrations along the section.

Thus, conventional geological methods do not allow to reliably detect the regularities of distribution of hydrocarbons along the section of the thickness studied.

In order to solve the problem we used probabilistic and statistical methods in particular regression analysis [16], which was carried out on three samples. The first sample included wells, where there is a tendency to decrease the content with an increase in depth. The second sample contain wells which hydrocarbon content increases with depth. For the third sample there is a chaotic change in hydrocarbons with a depth of sampling. Interrelations were studied with help of linear and nonlinear regressions in the nine most frequently used equations in mathematical statistics.

For the first scenario, the regression equation has the following type:

$$
K=0.353+0.923 / x \text { at } r=0.79,
$$

where $K$ is for concentration of hydrocarbon, $\mathrm{mg} / 100 \mathrm{~g}$ of soil.

Let us check how the actual statistical distribution of concentrations in depth is described 
by the statistical model. It is established that out of 19 wells drilled within the western part of the territory, the real distribution of the sum of concentrations in 12 corresponds to the model obtained i.e. the higher the depth the lower the concentration of hydrocarbons. Concentrations increase with depth in wells $6,10,14,19$. So, there is an inversion of the model. This group of wells represents the second sample to build a mathematical model that relates to the change in hydrocarbon concentrations with depth.

The calculated regression equation for the second sample looks like

$$
K=-1,454+1,126 \cdot h \text { at } r=0,79 .
$$

Distribution of hydrocarbons along the depth in wells 15 and 16 corresponds to the third adopted model.

Fig. 7 represents comparison of the obtained models of hydrocarbon distribution with related geological conditions. The first model corresponds to the conditions when clay loam is deposited on fractured mudstones, siltstones and sandstones having thickness is $2-3 \mathrm{~m}$. The second model is inherent in the conditions when clay loam is deposited on high permeable gravel soil, which is also underlain mudstones, siltstones and sandstones. The thickness of clay loam does not exceed 1.2-1.5 $\mathrm{m}$. Distribution of hydrocarbons in wells 15 and 16 refers to the third model and is irregular, due to the small thickness of loams underlying various soils (sands, gravel rocks) that are deposited on mudstones, siltstones and sandstones.

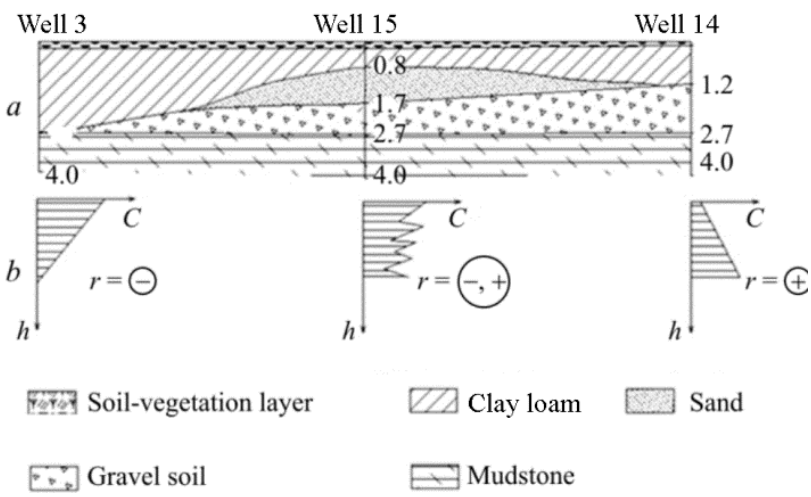

Fig. 7. Models of hydrocarbon distribution: $a$ - geological section; $b$ - graphs of hydrocarbon distribution; $C$ - concentration of hydrocarbons in soil, $\mathrm{mg} / 100 \mathrm{~g}$ of soil; $h$ - depth, $\mathrm{m} ; r$ - correlation coefficient
Based on above mentioned it is possible to describe the mechanism of distribution of hydrocarbons along a section of the rock massif.

When oil comes to the earth's surface then under the influence of gravitational forces, hydrocarbons penetrate into the rock massif $[26,27]$. If there is no additional supply of hydrocarbons to the rocks, the penetration process ends when equilibrium between gravitational forces and forces preventing the migration of hydrocarbons is reached. If the groundwater table is high enough and the mass of hydrocarbons is high, then hydrocarbons lie on the aquifer, which is a fluid barrier. Then there is a redistribution of hydrocarbons along the cross section. Due to gravitational forces hydrocarbons are accumulated in the upper contact zone of the aquifer. Due to the capillary uplift hydrocarbons are accumulated in the near-surface zone of the section.

The type of rocks and their sorption capacity, reservoir properties (porosity and permeability) and water saturation significantly influence such a hydrocarbon distribution process. In case the nearsurface zone of the earth is composed of sands that have low sorption capacity for hydrocarbons, high open porosity and high penetration properties, the zone of hydrocarbon contamination will be minimal compared to a zone composed of clays or loam (see Fig. 7) [28-30].

To assess the effect of soil types on the presence of anomalous concentrations, the following analysis was performed. Two groups of wells are identified within the western part of the territory on the map of total isoconcentrations. The first has increased concentrations; the second has background concentrations of hydrocarbons.

On the basis of two samples for thickness of various types of soils and average depth of their occurrence histograms were plotted. The following types of rocks were analyzed: soil-vegetation layer, clay loam, gravel soil of argillite, bulk soil, siltstone, sandstone, sand. Then, their individual informativity was determined by criteria $t$ and $F$ with a confidence probability of 0.95 .

Thickness of loam $\left(m_{2}\right)$ and burial depth (to some extent) of sandstones were informative indicators. Then thickness histograms were reconstructed into a probabilistic curve, the 
analysis of which allowed us to reveal the following regularity: the higher the thickness of loam the higher the probability $P(A)$ of high concentrations of hydrocarbons.

As a result of statistical processing it was established that presence of bulk soil affects the hydrocarbon content at a depth of $1 \mathrm{~m}$. We analyzed dependence of the amount of hydrocarbons at depth of $1 \mathrm{~m}$ from the thickness of the bulk soil. It was found that in presence of bulk soil the average amount of hydrocarbons is much higher than if there is no bulk soil.

\section{Conclusion}

Three models of distribution of hydrocarbons along a section are revealed, which are controlled by geological conditions (lithology and burial depth of an aquifer). Based on regularities revealed, mathematical models have been developed that allow to predict the degree of soil contamination by hydrocarbons using geological indicators such as thickness of loam and crushed rock, and depth of burial of sandstones.
1. Pushkareva M.V., Mai I.V., Seredin V.V., Leibovich L.O., Chirkova A.A., Vekovshinina S.A. Ekologicheskaia otsenka sredy obitaniia i sostoianiia zdorov'ia naseleniia na territoriiakh neftedobychi Permskogo kraia [Ecological assessment of the habitat and health status of the population in the territories of oil production in Perm Krai]. Zashchita okruzhaiushchei sredy $v$ neftegazovom komplekse, 2013, no.2, pp.40-45.

2. Seredin V.V., Pushkareva M.V., Leibovich L.O. Vozdeistvie ob"ektov khraneniia nefteproduktov na geologicheskuiu sredu [The impact of oil storage facilities on the geological environment]. Zashchita okruzhaiushchei sredy $v$ neftegazovom komplekse, 2015, no.3, pp.23-27

3. Seredin V.V. Otsenka geoekologicheskikh uslovii sanatsii territorii, zagriaznennykh neft'iu i nefteproduktami [Assessment of geoecological conditions for the rehabilitation of areas contaminated with oil and oil products]. Perm', Permskii gosudarstvennyi tekhnicheskii universitet, 1999, p.153.

4. Mazur I. Katastrofu eshche mozhno predotvratit' [The catastrophe can still be prevented]. Neft' Rossii, 1995, no. 3 , pp.4-9.

5. Usin V.V., Kumpanenko I.V., Ivanova N.A., Kartasheva N.S., Volovodov A.I.A method for preventing infiltration of oil and oil products into sandy soils. Source of the Document Russian Journal of General Chemistry, 2014, vol. 84 (11), pp. 2340-2345. DOI: $10.1134 / \mathrm{S} 1070363214110553$

6. Zhang Q., Wang G., Sugiura N., Zhang Z., Yang Y. Distribution of petroleum hydrocarbons in soils and the underlying unsaturated subsurface at an abandoned petrochemical site, North China. Hydrological Processes, 2014, 28 (4), pp.2185-2191. DOI: 10.1002/hyp.9770

7. Akbari A., Ardestani M., Shayegan J. Distribution and mobility of petroleum hydrocarbons in soil: Case study of the south pars gas complex, Southern Iran. Iranian Journal of Science and Technology - Transactions of Civil Engineering, 2012, 36 (C2), pp.265-275

8. Österreicher-Cunha P., Vargas Jr. E.d.A., Guimarães J.R.D., Lago G.P, Antunes F.d.S., da Silva M.I.P.Effect of ethanol on the biodegradation of gasoline in an unsaturated tropical soil. International Biodeterioration and Biodegradation, 2009, vol. 63 (2), pp.208-216. DOI: 10.1016/j.ibiod.2008.09.004

9. Sakari Halmemies, Siri Gröndahl, Keijo Nenonen, Tuula Tuhkanen. Estimation of the time periods and processes for penetration of selected spilled oils and fuels in different soils in the laboratory. Spill Science \& Technology Bulletin, 2003, vol.8, iss.5-6, pp.451-465. DOI: $10.1016 / \mathrm{S} 1353-2561(03) 00002-1$

10. Grimaz S., Allen S., Stewart J.R., Dolcetti G. Fast prediction of the evolution of oil penetration into the soil immediately after an accidental spillage for rapid-response purposes, available at: http://www.aidic.it/CISAP3/ webpapers/21Grimaz.pdf (accessed: 10 January 2016).

11. Zogala B., Dubiel, R., Zuberek W.M., RusinZogala M., Steininger M. Geoelectrical investigation of oil contaminated soils in former underground fuel base: Borne Sulinowo, NW Poland. Environmental Geology, 2009, 58 (1), pp.1-9. DOI: 10.1007/s00254-008-1458-y

12. Halmemies S., Möttönen Y., Tuhkanen T. Mitigating accidental fuel spills through power slurping. Fire Engineering, 2003, vol.156 (5), pp.100-105.

13. Malk V., Barreto Tejera E., Simpanen S., Dahl M., Mäkelä R., Häkkinen J., Kiiski A. NAPL migration and ecotoxicity of conventional and renewable fuels in accidental spill scenarios. Environmental Science and Pollution Research, 2014, vol.21, iss.16, pp.9861-9876. DOI: $10.1007 / \mathrm{s} 11356-014-2851-6$

14. Payne K.C., Jackson C.D., Aizpurua C.E., Rojas O.J., Hubbe M.A. Oil spills abatement: Factors affecting oil uptake by cellulosic fibers. Environmental Science and Technology, 2002, vol.46 (14), pp.7725-7730. DOI: $10.1021 / \mathrm{es} 3015524$

15. Iturbe R., Flores C., Castro A., Torres L.G. Sub-soil contamination due to oil spills in six oil-pipeline pumping stations in northern Mexico. Chemosphere, 2005, 68 (5), pp.893-906. DOI: 10.1016/j.chemosphere.2007.02.004

16. Galkin V.I., Seredin V.V., Bachurin B.A. Primenenie veroiatnostno-statisticheskikh modelei pri izuchenii raspredeleniia uglevodorodov $\mathrm{v}$ gruntakh $\mathrm{i}$ vybore tekhnologii ikh sanatsii [The application of probability-statistical models in the study of hydrocarbon distribution in soils and selection of technologies for their rehabilitation]. Perm': Permskii gosudarstvennyi tekhnicheskii universitet, 1999, $140 \mathrm{p}$.

17. Seredin V.V. Issledovanie prostranstvennogo raspredeleniia uglevodorodov $\mathrm{v}$ pochvogruntakh i vodakh na territoriiakh, zagriaznennykh neft'iu i nefteproduktami [Study of the spatial distribution of hydrocarbons in soil and water in areas contaminated by oil and oil products]. Perm', Permskii gosudarstvennyi tekhnicheskii universitet, 1998, 110 p. 
18. Seredin V.V., Leonovich M.F., Krasil'nikov P.A. Prognoz fil'tratsii uglevodorodov v dispersnykh gruntakh pri razrabotke neftianykh mestorozhdenii [Forecast transformation of dispersed hydrocarbons in soils in the development of oil fields]. Neftianoe khoziaistvo, 2015, no.5, pp.106-109

19. Seredin V.V., Iadzinskaia M.R. Zakonomernosti izmeneniia prochnostnykh svoistv glinistykh gruntov, zagriaznennykh nefteproduktami [Regularities of changes of strength characteristics of clay soils polluted by oil products]. Inzhenernaia geologiia, 2014, no.2, pp.26-32.

20. Seredin V.V., Starodumova A.O., Pushkareva M.V., Leibovich L.O. Eksperimental'noe izuchenie rasprostraneniia uglevodorodnogo zagriazneniia $\mathrm{v}$ geologicheskoi srede [Experimental study of hydrocarbon pollution spread in geological environment]. Neftianoe khoziaistvo, 2014, no.10, pp.131-133.

21. Matsievskii A.S., Pashkov M.V., Seredin V.V. $\mathrm{O}$ mekhanicheskikh svoistvakh glin $\mathrm{v}$ usloviiakh neftepererabatyvaiushchikh predpriiatii [About mechanical properties of the clays in conditions of petroleum-refining enterprises]. Sovremennye tekhnologii $v$ stroitel'stve. Teoriia i praktika, 2016, vol.2, pp.428-431.

22. Iadzinskaia M.R., Seredin V.V. Prognoz prochnostnykh svoistv gruntov, kak osnovanii sooruzhenii [Prognosis of strength properties of soils, as bases of structures]. Sovremennye tekhnologii $v$ stroitel'stve. Teoriia i praktika, 2016, vol.2, pp.476-478.

23. Zaichenko V.M., Maikov I.L., Torchinskii V.M., Shpil'rain E.E. Modelirovanie protsessov fil'tratsii uglevodorodov $\mathrm{v}$ gazokondensatnom plaste [Modeling of filtration processes of hydrocarbons in a gas condensate reservoir]. Teplofizika vysokikh temperatur, 2009, vol.47, no.5, pp.701-706.

24. Molokova N.V. Prikladnye aspekty modelirovaniia fil'tratsii zhidkikh uglevodorodov v poristoi srede [Applied aspects of modeling the filtration of liquid hydrocarbons in a porous medium]. Reshetnevskie chteniia, 2013, vol.2, no.17, pp.62-63.
25. Zaichenko V.M., Maikov I.L., Torchinskii V.M. Osobennosti fil'tratsii uglevodorodnykh smesei v poristykh sredakh [Features of filtration of hydrocarbon mixtures in porous media]. Teplofizika vysokikh temperatur, 2013, vol.51, no.6, pp.855.

26. Krasil'nikov P.A., Seredin V.V., Leonovich M.F. Issledovanie raspredeleniia uglevodorodov po razrezu gruntovogo massiva [Study of the distribution of hydrocarbons along a section of the soil massif]. Fundamental'nye issledovaniia, 2015, no.2-14, pp.3100-3104.

27. Krupoderov I.V., Moseiskin V.V. Modelirovanie uglevodorodnogo zagriazneniia geologicheskoi sredy na territorii Voronezhskoi neftebazy OAO «Voronezhnefteprodukt» [Modeling of hydrocarbon contamination of the geological environment on the territory of the Voronezh oil base of OJSC Voronezhnefteprodukt]. Gornyi informatsionno-analiticheskii biulleten', 2012, no.11, pp.273-281.

28. Seredin V.V., Pushkareva M.V., Leibovich L.O., Bakharev A.O., Tatarkin A.V., Filimonchikov A.A. Izmenenie geologicheskoi sredy pri razrabotke neftianykh mestorozhdenii v slozhnykh gorno-geologicheskikh usloviiakh [Geological environment changes during oil fields development in complex geological conditions]. Neftianoe khoziaistvo, 2014, no.12, pp.153-155.

29. Seredin V.V., Krasil'nikov P.A., Chizhova V.A. Vliianie viazkosti porovoi zhidkosti (uglevodorodov) na modul' deformatsii gliny [Influence of the pore fluid (hydrocarbons) viscosity on the deformation modulus of clay]. Inzhenernaia geologiia, 2015, no.4, pp.60-63.

30. Seredin V.V., Iadzinskaia M.R. Issledovaniia mekhanizma agregatsii chastits $\mathrm{v}$ glinistykh gruntakh pri zagriaznenii ikh uglevodorodami [Investigations of the mechanism of aggregation of particles in clay soils when their hydrocarbons are contaminated]. Fundamental'nye issledovaniia, 2014, no.8-6, pp.1408-1412.

\section{Библиографический список}

1. Экологическая оценка среды обитания и состояния здоровья населения на территориях нефтедобычи Пермского края / М.В. Пушкарева, И.В. Май, В.В. Середин, Л.О. Лейбович, А.А. Чиркова, С.А. Вековшинина // Защита окружающей среды в нефтегазовом комплексе. - 2013. - № 2. - С. 40-45.

2. Середин В.В., Пушкарева М.В., Лейбович Л.О. Воздействие объектов хранения нефтепродуктов на геологическую среду // Защита окружающей среды в нефтегазовом комплексе. - 2015. - № 3. - С. 23-27.

3. Середин В.В. Оценка геоэкологических условий санации территорий, загрязненных нефтью и нефтепродуктами / Перм. гос. техн. ун-т. - Пермь, 1999. - С. 153.

4. Мазур И. Катастрофу еще можно предотвратить // Нефть России. - 1995. - № 3. - С. 4-9.

5. A method for preventing infiltration of oil and oil products into sandy soils / V.V. Usin, I.V. Kumpanenko, N.A. Ivanova, N.S. Kartasheva, A.I. Volovodov // Source of the Document Russian Journal of General Chemistry. - 2014. - Vol. 84 (11). - P. 2340-2345. DOI: $10.1134 / \mathrm{S} 1070363214110553$
6. Distribution of petroleum hydrocarbons in soils and the underlying unsaturated subsurface at an abandoned petrochemical site, North China / Q. Zhang, G. Wang, N. Sugiura, Z. Zhang, Y. Yang // Hydrological Processes. 2014. - 28 (4). - P. 2185-2191. DOI: 10.1002/hyp.9770

7. Akbari A., Ardestani M., Shayegan J. Distribution and mobility of petroleum hydrocarbons in soil: Case study of the south pars gas complex, Southern Iran // Iranian Journal of Science and Technology - Transactions of Civil Engineering. 2012. - 36 (C2). - P. 265-275.

8. Effect of ethanol on the biodegradation of gasoline in an unsaturated tropical soil / P. Österreicher-Cunha, Jr. E.d.A. Vargas, J.R.D. Guimarães, G.P. Lago, F.d.S. Antunes, M.I.P. da Silva // International Biodeterioration and Biodegradation. - 2009. - Vol. 63 (2). P. 208-216. DOI: 10.1016/j.ibiod.2008.09.004

9. Estimation of the time periods and processes for penetration of selected spilled oils and fuels in different soils in the laboratory / Sakari Halmemies, Siri Gröndahl, Keijo Nenonen, Tuula Tuhkanen // Spill Science \& Technology Bulletin. - 2003. - Vol. 8, iss. 5-6. - P. 451465. DOI: 10.1016/S1353-2561(03)00002-1 
10. Fast prediction of the evolution of oil penetration into the soil immediately after an accidental spillage for rapid-response purposes [Электронный pecypc] / S. Grimaz, S. Allen, J.R. Stewart, G. Dolcetti. - URL: http://www.aidic.it/CISAP3/webpapers/21Grimaz.pdf (дата обращения: 10.12.2016).

11. Geoelectrical investigation of oil contaminated soils in former underground fuel base: Borne Sulinowo, NW Poland / B. Zogala, R. Dubiel, W.M. Zuberek, M. RusinZogala, M. Steininger // Environmental Geology. - 2009. 58 (1). - P. 1-9. DOI: 10.1007/s00254-008-1458-y

12. Halmemies S., Möttönen Y., Tuhkanen $T$. Mitigating accidental fuel spills through power slurping // Fire Engineering. - 2003. - Vol. 156 (5). - P. 100-105.

13. NAPL migration and ecotoxicity of conventional and renewable fuels in accidental spill scenarios / V. Malk, E. Barreto Tejera, S. Simpanen, M. Dahl, R. Mäkelä, J. Häkkinen, A. Kiiski // Environmental Science and Pollution Research. - 2014. - Vol. 21, iss. 16. - P. 98619876. DOI: 10.1007/s11356-014-2851-6.

14. Oil spills abatement: factors affecting oil uptake by cellulosic fibers / K.C. Payne, C.D. Jackson, C.E. Aizpurua, O.J. Rojas, M.A. Hubbe // Environmental Science and Technology. - 2002. - Vol. 46 (14). P. 7725-7730. DOI: 10.1021/es3015524.

15. Sub-soil contamination due to oil spills in six oil-pipeline pumping stations in northern Mexico / R. Iturbe, C. Flores, A. Castro, L.G. Torres // Chemosphere. - 2005. - 68 (5). - P. 893-906. DOI: $10.1016 /$ j.chemosphere.2007.02.004

16. Галкин В.И., Середин В.В., Бачурин Б.А. Применение вероятностно-статистических моделей при изучении распределения углеводородов в грунтах и выборе технологий их санации / Перм. гос. техн. ун-т. - Пермь, 1999. - 140 с.

17. Середин В.В. Исследование пространственного распределения углеводородов в почвогрунтах и водах на территориях, загрязненных нефтью и нефтепродуктами / Перм. гос. техн. ун-т. - Пермь, 1998. - 110 с.

18. Середин В.В., Леонович М.Ф., Красильников П.А. Прогноз фильтрации углеводородов в дисперсных грунтах при разработке нефтяных месторождений // Нефтяное хозяйство. - 2015. - № 5. - С. 106-109.

19. Середин В.В., Ядзинская М.Р. Закономерности изменения прочностных свойств глинистых грунтов, загрязненных нефтепродуктами // Инженерная геология. - 2014. - № 2. - С. 26-32.

20. Экспериментальное изучение распространения углеводородного загрязнения в геологической среде /
В.В. Середин, А.О. Стародумова, М.В. Пушкарева, Л.О. Лейбович // Нефтяное хозяйство. - 2014. - № 10. C. $131-133$.

21. Мациевский А.С., Пашков М.В., Середин В.В. о механических свойствах глин в условиях нефтеперерабатывающих предприятий // Современные технологии в строительстве. Теория и практика. 2016. - T. 2. - C. 428-431.

22. Ядзинская М.Р., Середин В.В. Прогноз прочностных свойств грунтов, как оснований сооружений // Современные технологии в строительстве. Теория и практика. - 2016. - Т. 2. - С. 476-478.

23. Моделирование процессов фильтрации углеводородов в газоконденсатном пласте / В.М. Зайченко, И.Л. Майков, В.М. Торчинский, Э.Э. Шпильрайн // Теплофизика высоких температур. 2009. - T. 47, № 5. - С. 701-706.

24. Молокова Н.В. Прикладные аспекты моделирования фильтрации жидких углеводородов в пористой среде // Решетневские чтения. - 2013. T. 2, № 17. - C. 62-63.

25. Зайченко В.М., Майков И.Л., Торчинский В.М. Особенности фильтрации углеводородных смесей в пористых средах // Теплофизика высоких температур. - 2013. - Т. 51, № 6. - С. 855.

26. Красильников П.А., Середин В.В., Леонович М.Ф. Исследование распределения углеводородов по разрезу грунтового массива // Фундаментальные исследования. - 2015. - № 2-14. - С. 3100-3104.

27. Круподеров И.В., Мосейскин В.В. Моделирование углеводородного загрязнения геологической среды на территории Воронежской нефтебазы ОАО «Воронежнефтепродукт» // Горный информационно-аналитический бюллетень. - 2012. - № 11. C. 273-281.

28. Изменение геологической среды при разработке нефтяных месторождений в сложных горногеологических условиях / В.В. Середин, М.В. Пушкарева, Л.О. Лейбович, А.О. Бахарев, А.В. Татаркин, А.А. Филимончиков // Нефтяное хозяйство. - 2014. № 12 . - C. $153-155$.

29. Середин В.В., Красильников П.А., Чижова В.А. Влияние вязкости поровой жидкости (углеводородов) на модуль деформации глины // Инженерная геология. 2015. - № 4. - С. 60-63.

30. Середин В.В., Ядзинская М.Р. Исследования механизма агрегации частиц в глинистых грунтах при загрязнении их углеводородами // Фундаментальные исследования. - 2014. - № 8-6. - С. 1408-1412.

Please cite this article in English as:

Krasilnikov P.A., Seredin V.V. Study of regularities and construction of mathematical models of hydrocarbon distribution in a section on territories of oil treatment enterprises. Perm Journal of Petroleum and Mining Engineering, 2017, vol.16, no.2, pp. 191-200. DOI: 10.15593/2224-9923/2017.2.10

Просьба ссылаться на эту статью в русскоязычных источниках следующим образом:

Красильников П.А., Середин В.В. Изучение закономерностей и построение математических моделей распределения углеводородов по разрезу на территориях нефтеперерабатывающих предприятий // Вестник Пермского национального исследовательского политехнического университета. Геология. Нефтегазовое и горное дело. - 2017. - Т.16, №2. - С.191-200. DOI: $10.15593 / 2224-9923 / 2017.2 .10$ 